\title{
Deleted in Lung and Esophageal Cancer Protein 1
}

National Cancer Institute

\section{Source}

National Cancer Institute. Deleted in Lung and Esophageal Cancer Protein 1. NCI

Thesaurus. Code C26218.

Deleted in lung and esophageal cancer protein 1 (1755 aa, $196 \mathrm{kDa}$ ) is encoded by the human DLEC1 gene. This protein may play a role in tumor suppression. 